\title{
Diskursiv diskriminering av regnbågsfamiljer. En analys av argument mot likställande av homo- och heterosexuellas föräldraskap
}

\section{ANNA MALMQUIST \& KARIN ZETTERQVIST NELSON}

Genom två lagändringar har nya juridiska möjligheter till adoption och assisterad befruktning öppnats för samkönade par. Den här artikeln analyserar retoriken $i$ delar av den debatt som följt med förändringarna. I sättet att konstruera regnbågsfamiljer som »de andra« uppstår en diskursiv diskriminering på heteronormativa grunder.

\section{Introduktion}

På senare år har flera författningsändringar genomförts i syfte att motverka diskriminering på grund av sexuell orientering. När det gäller familj och föräldraskap har samkönade par på två viktiga områden fått juridisk status som motsvarar de olikkönade parens. År 2003 genomfördes en

Anna Malmquist, fil.mag. och examinerad psyko$\log$

Karin Zetterqvist Nelson, leg. psykolog, universitetslektor vid IBL, Linköpings universitet samt docent, vid tema Barn, Linköpings universitet ändring i lagen om registrerat partnerskap (SFS 1994:1117) som innebar att sam- och olikkönade par likställdes juridiskt, både vid gemensam adoption och styvbarnsadoption. Några år senare, 2005, fick lesbiska par tillgång till fertilitetsbehandling i svensk sjukvård, vilket idag regleras enligt lagen om genetisk integritet m.m. (SFS 2006:351). Lagförändringarna skapade stor debatt och längs vägen uttryckte många remissinstanser kritik mot förslagen. Störst uppmärksamhet väckte adoptionsfrågan och en lång rad samhällsinstanser, organisationer och enskilda svenskar tog markant olika ställ- 
ning till propositionen om likabehandling (prop. 2001/02:123). När SOU 2001:10, Barn $i$ homosexuella familjer, gick ut på remiss vände sig flera tunga remissinstanser mot förslaget att låta registrerade partner gemensamt prövas som adoptivföräldrar. Här fanns Sveriges Psykologförbund, som vi närmare kommer att granska, tillsammans med bland andra Svenska läkaresällskapet, Socialstyrelsen, Barnombudsmannen, BRIS, Statens nämnd för internationella adoptioner, Adoptionscentrum och Svenska kyrkan. Positiva till lagförslaget var däremot bland andra Folkhälsoinstitutet, HomO, RFSL och RFSU. Intensiteten i debatten antydde att viktiga frågor stod på spel, som exempelvis rörde normer och värderingar för hur en familj antas se ut, förväntningar på föräldraskap och barndom, liksom hur sexualitet bör ta sig uttryck.

I blickfånget för den här artikeln finns Sveriges Psykologförbund (nedan Psykologförbundet) och två remissvar (Ahlin \& Hjelm 2004, Danielsson \& Graff-Cederström 2001) som förbundet avgivit till justitiedepartementet i dessa frågor. ${ }^{1}$ Vårt intresse för just Psykologförbundet har sin grund i, för det första, artikelförfattarnas professionstillhörighet som psykologer. För det andra, Psykologförbundet som en viktig röst för tillvaratagandet av barns behov och värnandet om barns bästa ger en särskild tyngd till dess ställningstaganden, vilket

1 Psykologförbundet är det fackförbund som organiserar psykologer, psykologstudenter och forskare inom psykologi och pedagogik (http:// www.psykologforbundet.se). Organisatoriskt återfinns Psykologförbundet inom Sveriges Akademikers Centralorganisation. även lyftes fram då den politiska debatten pågick (se exempelvis Riksdagens snabbprotokoll 2001/02:120). Psykologin som den disciplin där människors utveckling studeras i termer av normalitet och avvikelse breddar också intresset för hur homosexuella familjebildningar, så kallade regnbågsfamiljer, framställs inom just psykologernas professionssammanslutning. I intervjuer där personer i ledningen för Psykologförbundet reflekterar kring remissvaren framträder två olika diskurser om den homosexuella familjen, vilka har analyserats och diskuteras som exempel på hur diskursiv diskriminering (Boréus 2006) uppstår och upprätthålls. ${ }^{2}$ Psykologförbundets argumentation avvisades förvisso ur rättsligt perspektiv, med hänvisning till diskriminering på grund av sexuell orientering. Argumentationen har sålunda redan definierats som diskriminerande på rättsliga grunder. Vi menar dock att det är av samhällsintresse att närmare studera hur denna diskriminering åstadkoms och upprätthålls på ett språkligt - diskursivt - plan och dess normativa grunder. Detta dels för att det vid tiden för adoptionsdebatten var många förhållandevis starka aktörer som använde en likartad argumentation, dels för att den speglar attityder och perspektiv som fortfarande kommer till uttryck, inte minst när regnbågsföräldrar och -barn möter olika samhällsinstanser, som sociala myndigheter, hälso- och sjukvård, förskolor och skolor.

2 Artikeln bygger på en psykologexamensuppsats (Malmquist 2007), som här avgränsats med fokus på diskriminering. Intervjumaterialet som låg till grund för psykologexamensuppsatsen har inte bearbetats ytterligare, utan alla citat återfinns i det aktuella examensarbetet. 
Artikeln inleds med ett avsnitt om tidigare forskning och en presentation av våra teoretiska utgångspunkter. Därefter följer ett avsnitt om de aktuella utredningarna, liksom om den förändrade lagstiftning som blev resultatet. Mot den bakgrunden presenteras sedan problemområdet och våra centrala frågor, varefter resultatet av analysen redovisas. Artikeln avslutas med en slutdiskussion.

\section{Tidigare forskning och teoretiska utgångspunkter}

Attityder till homosexuella eller homosexualitet utgör ett område inom socialpsykologisk forskning, både i Sverige och internationellt (se exempelvis Anderssen 2002, Herek 2002, Ratcliff et al. 2006, SOU 2001:10), där syftet ofta har varit att genom enkäter eller formulär kartlägga och beskriva allmänna attityder i befolkningen eller i någon specifik grupp. Kritik mot denna ofta kvantitativt inriktade och individfokuserade forskning har framförts med hänvisning till att negativa attityder till homosexualitet framställs som psykologiska fenomen ("homofobi») snarare än som uttryck för sociala och kulturella normer och strukturer (Clarke 2000, Speer \& Potter 2000). Det är en kritik med förankring i ett diskursteoretiskt perspektiv (se exempelvis Billig 1991, Potter \& Wetherell 1987), en forskningstradition inom vilken attityder och argument ses som en produkt av interaktion och kontext snarare än kognition. Uppmärksamheten riktas då istället mot attityder och åsikter som retoriska verktyg i de sammanhang de aktualiseras (Speer \& Potter 2000).
Här finns ett intresse för hur berättare och talare gör för att få den egna ansatsen att framstå som "självklar" och "sann", liksom hur berättaren går tillväga för att konstruera en trovärdig version av ett visst fenomen eller sakfråga (Potter \& Wetherell 1987).

Hur argumentation mot homosexuellas föräldraskap retoriskt byggs upp och framförs har tidigare analyserats i ett par studier av den brittiska forskaren Victoria Clarke (2000, 2001). Argumentation i media, liksom i intervjuer med studenter, framhärdar i och byggs upp kring påståenden att barnen till homosexuella saknar nödvändiga förebilder, att de riskerar en förvirrad sexualitetsutveckling samt att de utsätts för mobbning (Clarke 2001). I sin studie av forskares argumentation mot homosexuellas föräldraskap lyfter Clarke (2000) bland annat fram hänvisningar till common sense som retoriskt viktiga för att styrka forskningsresultat.

I linje med ovan beskrivna forskningstradition utgår vi ifrån ett diskursanalytiskt perspektiv. Här ses talet aldrig som neutralt och genomskinligt, utan talet ses som handling: "talet åstadkommer något " (Magnusson 2006 s. 242). Talet om ett fenomen, en sak, en princip, o.s.v., kan ses som en "diskurs». Begreppet "diskurs» syftar då på det sätt varpå språket används i framställningen av ett fenomen, såsom förekomst av vissa ord, uttryck och beteckningar. En diskurs kan på så vis ses som styrd av regler och premisser som påverkar framställning och innehåll. ${ }^{3}$ Samtidigt omfattar diskursperspektivet en syn på språket som både arbiträrt och för-

3 Se Eva Magnussons (2006) diskussion av begreppet diskurs. 
änderligt; allting går att uttrycka på annat sätt, de regler och premisser som styr en diskurs utmanas och alternativa versioner förhandlas fram och vinner ibland tolkningsföreträde. Vi är inspirerade av diskursiv psykologi, såsom den utvecklats av Eva Magnusson (2006, se också Edwards \& Potter 1992). Här studeras diskurser i social interaktion och Magnusson (2006) tar fasta på en berättares intresse att framställa sin syn på verkligheten som trovärdig. I detta syfte använder människor en rad retoriska och argumentativa tekniker när de talar, något som blir särskilt tydligt i de sammanhang då talaren har en ståndpunkt att försvara eller argumentera för. I vår analys av argumentation och retoriska strategier tar vi hjälp av Edwards och Potters (1992) diskursiva tekniker (enligt översättning av Magnusson 2006): kategoriberättande, livliga berättelser, trovärdig narrativ sekvens, systematisk vaghet, extremfallsformulering, kontraster och normativitet. Gemensamt för dessa diskursiva tekniker är att de har en faktaskapande karaktär, där talaren framställer något som faktiskt snarare än som en personlig åsikt. Genom analys av subjektspositioner tillförs vidare en dimension där talarens position i förhållande till det sagda kan granskas.

Inför uppgiften att närmare granska och synliggöra diskrimineringens diskursiva karaktär och uppbyggnad har vi vidare knutit an till en inriktning inom diskursteori, som utvecklats av statsvetare Kristina Boréus $(2005,2006)$ i resonemang och analyser av diskursiv diskriminering. Diskursiv diskriminering definieras då som »...unfavourable treatment of members of an (alleged) group on account of their membership in that group. Discursive discrimination is such treatment carried out by linguistic means» (Boréus 2006 s. 408). Boréus har i analyser av texter utvecklat en mer "precis begreppsapparat för vad diskursiv diskriminering är« (Boréus 2005 s. 3).

En grundläggande förutsättning för diskursiv diskriminering är enligt Boréus (2005) »kategorisering». Denna görs via språket när individer beskrivs som tillhörande en grupp, på grundval av vissa specifika egenskaper, vilka i det specifika sammanhanget ges en särskild innebörd. I en process som benämns "distansering" vill Boréus peka på hur dessa egenskaper ges innebörder som framhäver skillnader mellan olika kategorier, som sedan enligt ett norm- och värdesystem värderas till förmån för den kategori talaren/skribenten själv tillhör. Via en "vi-och-dom"logik skapas därmed "de andra», vilket tar sig olika uttryck, men som resulterar i diskriminering. Dessa skilda språkliga strategier/handlingar har Boréus (2005) presenterat i en typologi: exkludering, nedvärdering, objektifiering samt förslag som pekar på icke-språklig negativ särbehandling. I vår analys av intervjusamtal om samtida "homosexuella familjer, föräldrar, individer och parı använder vi delar av Boréus typologi för att undersöka hur diskursiv diskriminering uppstår till följd av en retorisk distansering via argumentation kring dessa "de andra». Vi har också valt att i vissa sammanhang tala om "problematisering" som ett sätt att skapa distans och konstruera homosexuella föräldrar som "de andra", ett begrepp hämtat från Essed (1991). Detta blir ett sätt att pröva typologin på ett annat slags datamaterial 
(samtal) än det Boréus använt (offentligt tryck och mediatexter).

\section{Utredningar och förändrad lagstiftning}

De senaste decennierna har rättsligt föräldraskap för homosexuella vid ett flertal tillfällen aktualiserats i svenska sammanhang $i$ anslutning till att homosexuella samlevnads- och familjefrågor behandlats i offentliga utredningar (Ds 2004:19, SOU 1983:42, SOU 1984:63, SOU 1993:98, SOU 2001:10, SOU 2007:3). Fram till publiceringen av SOU 2001:10, Barn $i$ homosexuella familjer, var dock inställningen samstämmig i utredningarna: gemensamt utövande av juridiskt föräldraskap skulle förbehållas olikkönade par. Genom att föreslå en förändrad lagstiftning som gav registrerade partner möjlighet att gemensamt prövas som adoptivföräldrar, möjlighet för en registrerad partner att adoptera sin partners biologiska eller adopterade barn (s.k. styvbarnsadoption) samt möjlighet för lesbiska par att erhålla assisterad befruktning inom den svenska sjukvården bröt utredningen om barn i homosexuella familjer (SOU 2001:10) trenden. Förslagen tog fasta på att skillnader i villkor för barn som växer upp med homo- respektive heterosexuella föräldrar inte förelåg på ett sådant vis att skild lagstiftning ansågs sakligt motiverad. I adoptionsfrågor likställdes därmed registrerade partner med heterosexuella makar år 2003 (Ju 03.03). Frågan om assisterad befruktning för lesbiska par blev dock föremål för ytterligare en utredning (Ds 2004:19), innan en lagändring år
2005 öppnade dörrarna för sådan behandling i sjukvårdens regi (regleras idag i SFS 2006:351). Centralt i denna utredning var hur den kvinna som inte fött barnet skulle benämnas i lagtext, där förslaget att benämna henne på samma vis som den kvinna som fött barnet, som "mor", lades fram (Ds 2004:19). I den proposition som antogs av riksdagen ändrades dock benämningen till »förälder» (prop. 2004/05:137).

\section{Problemområde, syfte och centrala frågor}

Psykologförbundet var i fråga om gemensam adoption alltså en av de aktörer som avvisade förslaget om likställande. I förbundets remissvar till SOU 2001:10 fastslås att "Sveriges Psykologförbund anser inte att det för närvarande finns något som talar för att möjligheten att adoptera barn bör utvidgas till homosexuella familjer" (Danielsson \& Graff-Cederström 2001 s. 1). Inställningen motiveras framförallt med ett för dåligt forskningsunderlag kring adoptivbarns utsatthet. Vidare framförs att det finns en risk att ett dubbelt annorlundaskap skulle vara påfrestande för den som är utlandsadopterad till en homosexuell familj. Angående styvbarnsadoption var inställningen dock en annan, Psykologförbundet var positivt till att låta en registrerad partner adoptera sin partners biologiska barn. Även i fråga om assisterad befruktning för lesbiska par uttalar sig förbundet positivt, man har wingenting att invända" (Danielsson \& Graff-Cederström 2001 s. 3). Till utredningen Ds 2004:19 avgav Psykologförbundet ett remissvar 
där man vände sig mot förslaget att juridiskt benämna den kvinna i ett lesbiskt par som inte föder barnet som "mor" (Ahlin \& Hjelm 2004). Det framförs här att ett likvärdigt föräldraskap kan vara svårt att uppnå för kvinnorna, där bara den ena har genetiska band till barnet.

Vi är intresserade av Psykologförbundets ställningstaganden i den aktuella frågan. Det övergripande syftet är att analysera deras argumentation med fokus på diskriminering. Hur framskrivs skillnader mellan homo- och heterosexuellas föräldraskap? Hur motiveras en skild lagstiftning och vilka expertkunskaper åberopas? Hur är talet (diskursen) om det samkönade föräldraskapet konstruerat? Vilka konsekvenser får detta tal för ställningstagandet $\mathrm{i}$ frågan om adoption respektive assisterad befruktning?

\section{Metod och bearbetning av data}

Det insamlade materialet består av enskilda intervjuer med nio personer som funnits inom ledningen för Psykologförbundet, i dess förbundsstyrelse eller som anställd på dess kansli, vid tidpunkten för författandet av endera eller båda remissvaren. Intervjuerna genomfördes av Anna Malmquist omkring årsskiftet 2006-2007. Intervjupersonerna utgörs av tre kvinnor och sex män med en medelålder på 54 år vid intervjutillfället och ett åldersspann på 16 år mellan äldst och yngst. Till sin profession är åtta av intervjupersonerna psykologer, medan en är jurist. De intervjuade psykologerna tillfrågades i intervjun om sin teoretiska inriktning eller skolbildning. Av dessa åtta valde fyra att betona psykologutbildningens bredd eller benämna den som en generalistutbildning. Övriga fyra lyfte fram en psykodynamisk eller psykoanalytisk inriktning på sitt arbete eller sin utbildning.

Med hjälp av frågor där citat från remissvaren inkluderades uppstod ett material där intervjupersonerna i öppna och halvstrukturerade intervjuer gavs möjlighet att reflektera kring homosexuellas föräldraskap och de ställningstaganden förbundet gjort några år tidigare. Intervjuerna transkriberades i sin helhet, vilket omfattar 149 sidor skriven text. Genom ett systematiskt bearbetande av transkriptionerna, där varje intervju sammanfattades sida för sida och fråga för fråga kunde mönster i reflektion och argumentation, textens diskurser, analyseras. ${ }^{4}$ För att illustrera en retorisk strategi eller ett specifikt ställningsstagande presenteras utdrag ur intervjuerna i excerpter. Intervjuarens kommentarer återfinns i parenteser. I diskussionerna används kursiverade citat, som hänvisar till excerpterna, för att tydliggöra tolkningar och resonemang.

I remissvaren hade Psykologförbundet frågor kring tre former av familjebildning att ta ställning till: gemensam adoption för homosexuella par, styvbarnsadoption för en homosexuell partner samt assisterad befruktning för lesbiska par. De intervjuade psykologernas (åtta totalt) ståndpunkter uppvisar i likhet med förbundets officiella inställning en skiljelinje mellan frågan om gemensam, ofta likställt med internationell, adoption och de båda övriga frågorna. Samtliga intervjuade psykologer uttrycker en negativ inställning till gemensam adop-

4 Se not 5 ovan. 
tion för homosexuella par, medan flertalet uttalar sig positivt om styvbarnsadoption (sju av åtta) och assisterad befruktning (sex av åtta). Den intervjuade juristen uttrycker däremot en positiv inställning till samtliga frågor, i linje med ståndpunkterna uttryckta i lagförslagen. Diskussionen avgränsas därför till de intervjuade psykologerna.

I intervjumaterialet har två skilda diskurser identifierats som båda framställer den homosexuella familjen som problematisk, som »de andra». ${ }^{5}$ Den ena diskursen framträder i samtliga psykologintervjuer och handlar om samhällets attityder till homosexualitet. Diskursen konstruerar föreställningen om en påfrestning som tillförs barn med homosexuella föräldrar utifrån, problem som är kopplade till omständigheter utanför familjen. Den omfattar beskrivningar av negativa samhällsattityder till homosexualitet, som i sin tur sägs ge upphov till ett annorlundaskap som innebär påfrestningar för barnet och familjen. Utifråndiskursen framträder främst i samtal kring internationell adoption. Den andra diskursen handlar om barnets psykologiska utveckling i den homosexuella familjen och fokuserar på svårigheter som antas tillstöta inifrän familjen. En sådan diskurs framställs framförallt $i$ fem psykologintervjuer medan de tre övriga ibland uttrycker ett avståndstagande från denna diskurs. Inifråndiskursen blir särskilt synlig i samtal kring assisterad befuktning för lesbiska par och resulterar i föreställningen om risk förknippad med avsaknad av ett manligt identifikationsobjekt. Vidare

5 Delar av intervjuerna där homosexuellas föräldraskap framställs som oproblematiskt återfinns i Malmquist (2007). uppstår i inifråndiskursen en föreställning om en rollförvirring som uppstår till följd av fler än en förälder av samma kön.

Frågan om styvbarnsadoption blev aldrig föremål för problematisering, utan kraven på likabehandling ansågs från Psykologförbundets sida relevanta.

\section{Utifråndiskursen}

\section{Samhällets attityder}

I detta avsnitt kommer vi att beskriva hur samhällsattityder till homosexualitet framställs på ett sätt som frammanar bilden av en negativ påverkan på det barn som växer upp i en homosexuell familj. I flertalet intervjuer är beskrivningarna av dessa attityder ganska kortfattade och fåordiga. Den homosexuella familjen framställs som något "lite speciellt», vilket i nästa steg blir definierat som negativt när det framställs som att barnet riskerar att bli "ifraggasatt». Ett par intervjupersoner är dock mycket målande när de återger en bild av ett i samhället starkt avståndstagande från homosexuella.

\section{Excerpt 1}

Och sedan är det ju helt uppenbart så att väldigt många vuxna har fortfarande, såatt säga, en massa fördomar gentemot människor som är homosexuella och tycks tro att det skulle vara någon slags lägre stående varelse eller hemska på olika sätt och, ja ( $\mathrm{mm}$ ). Om man drar paralleller för de tror att det smittar nästan eller nästan så kan man få det intrycket ibland så att.. [suck]. IP 9 
Ett livligt berättande används retoriskt i framställningen ovan för att skapa trovärdighet i beskrivningarna av samhällets attityder. Här uttrycks en föreställning om hur homosexuella uppfattas av andra som närmast omänskliga, "någon slags lägre stående varelse eller hemska på olika sätt". Attityderna framstår i excerptet som allmängiltiga i beskrivningen att "väldigt många vuxna har fortfarande ... en massa fördomar". Genom det förstärkande uttrycket att detta är "ju helt uppenbart" framstår det som att intervjupersonen eftersträvar att få sin bild att vara självklar snarare än förhandlingsbar. I excerptet vidrörs även föreställningen om homosexualitet som en sjukdom i uttrycket att människor "tror att det smittar". Psykologens sätt att sucka i excerptet ovan kan dock uppfattas som ett sätt att markera avståndstagande från de presenterade negativa attityderna.

När barn till homosexuella lyfts in i diskursen om samhällets negativa attityder framställs problem i termer av "belastning" och "risk", ett språkbruk som är vanligt i en nutida psykologisk expertdiskurs om utsatta barn.

\section{Excerpt 2}

...så skulle man då åstadkomma en.. en viss risk för att ytterligare då belasta barnets situation. Att bli alltså typ, det här vanliga, att.. att.. att man uppfattas.. att det uppfattas väldigt, om man säger, udda och knepigt av kamrater och omgivning att.. i skola och annat.. att man då har två mammor eller tvåpappor $(\mathrm{mm})$. IP 8

I detta sammanhang framställs "kamrater" och "omgivning" som de aktörer som skulle kunna uppfatta det samkönade föräldraparet som väldigt "udda och knepigt", vilket alltså riskerar att "belasta barnets situation". Uttrycket "det här vanliga" har effekten att en mobbningsrisk framstår som uppenbar.

I intervjumaterialet finns få beskrivningar av intervjupersonernas egna negativa reaktioner på homosexualitet, tvärtom framställer flera intervjupersoner sig själva som liberala och markerar ett avstånd till negativa samhällsattityder. När den negativa inställningen till homosexualitet uttrycks explicit görs det, liksom i excerptet ovan, genom att intervjupersonerna lånar en annan röst, en samhällets röst som kommer till uttryck via aktörer som »kamrater och omgivning" eller "väldigt många vuxna". I Boréus typologi $(2005,2006)$ beskrivs nedvärdering som en diskriminerande diskursiv strategi. Med detta sätt att tala uppstår nedvärderingen på ett mer indirekt vis, utan att talaren själv behöver ta ansvar för den.

\section{Det dubbla annorlundaskapet}

I remissvaret från 2001, av Danielsson och Graff-Cederström, presenterar Psykologförbundet alltså sin inställning i adoptionsfrågan. Argumentationen för ett «nej« till gemensam adoption konstrueras kring hänvisning till den risk ett s.k. "dubbelt annorlundaskap« skulle innebära, nämligen att både vara utlandsadopterad och växa upp i en homosexuell familj. Även i intervjuerna används det dubbla annorlundaskapet som ett nyckelargument och flera av de intervjupersoner som varit fåordiga i sina 
beskrivningar av samhällets attityder till homosexualitet skapar livliga och målande berättelser när de talar om adoption.

\section{Excerpt 3}

...alltså rent generellt kan man ju utgå ifrån att barn som rycks upp frain sin egen bakgrund ( $\mathrm{mm}$ ) och, tänk dig själv, ett kolsvart barn ifrån mörkaste Afrika som placeras i en familj uppe i.. i Norrland ( $\mathrm{mm}$ ), där det kanske inte finns några fler ( $\mathrm{mm}$ ) färgade barn, då $(\mathrm{mm})$, det är klart att det finns en större påfrestning för dessa barn om det dessutom skulle hamna i en minoritet bland homosexuella par, till exempel, det är klart att det blir en pålastning ( $\mathrm{mm}$ ), att förhålla sigtill $(\mathrm{mm})$. IP 4

I excerptet ovan skapas ett dramatiskt berättande, "tänk dig själv", säger psykologen och visar så att här kommer en scen att målas upp. Som retoriskt grepp används en extremfallsformulering i den beskrivning som följer, där just extremer ger färg åt berättelsen om adoptivbarnets utsatthet. Det handlar om ett barn som "rycks upp" från sin negen" bakgrund. Barnet är »kolsvart" ifrån "mörkaste Afrika" och placeras i en annan extrem "uppe i.. i Norrland" där det "kanske inte finns några fler" färgade barn. Samtidigt som utsagan byggs upp av ytterligheter, görs ett anspråk på att låta den vara allomfattande genom hänvisandet till att "rent generellt kan man ju utgå ifrån" detta. Beskrivningen av annorlundaskapet i att tillhöra en homosexuell familj är dock inte alls lika målande. Intervjupersonen gör det vaga konstaterandet att det blir en större "påfrestning" att hamna i en "minoritet». Kontrasterna, extremerna och för- stärkningsorden saknas generellt i flertalet beskrivningar av den homosexuella delen av annorlundaskapet, men är desto vanligare när det kommer till problematik som hänförs internationella adoptioner.

När det dubbla annorlundaskapet används argumenterande i intervjuerna flyttas alltså tyngdpunkten från frågan om homosexuella familjer till internationell adoption. Därmed blir det adoptionsfrågan snarare än homosexualitet som bär upp det retoriska huvudargumentet för att behålla skild lagstiftning. Att presentera förslag som pekar på negativ särbehandling - inte bara i språket utan av icke-språklig karaktär - är en av strategierna i Boréus typologi för diskursiv diskriminering. I detta sammanhang presenteras inte nya förslag av diskriminerande art, utan argumentationen syftar till att kvarhålla en särskiljande lagstiftning. Detta visar hur frågorna om homosexuellas rättigheter finns i en liberaliseringsprocess där förslag om ökade möjligheter är aktuella, inte förslag om ytterligare begränsningar.

I samtal kring assisterad befruktning förekommer i intervjuerna knappast diskursen om negativa samhällsattityder som tillförs familjen utifrån. Tvärtom framställs ofta assisterad befruktning som "en annan sak" eller "på ett helt annat plan", vilket gör frånvaron av utifråndiskursen påtaglig. Homosexualitet konstrueras som en avgörande risk i en specifik kontext, vid internationell adoption, en "risk" som inte tillskrivs betydelse i sammanhang där det framgår att det finns en biologisk/genetisk koppling mellan barn och förälder. Det uppstår en argumentation som understödjer ett »ja» till assisterad befruktning och ett 
"nej" till gemensam adoption. Skiljelinjen mellan frågorna synliggör hur det biologiska föräldraskapet tillskrivs en avgörande betydelse som i sin tur får effekten att den problematisering av det homosexuella föräldraskapet som anförts tidigare, när det gällde adoption, inte längre görs relevant. Den diskursiva diskriminering som skapas i frågor som rör assisterad befruktning har en annan karaktär, den byggs upp på andra grunder. Här synliggörs en diskurs som problematiserar att föräldraskap utövas av två kvinnor utan män - en diskurs om problem som tillkommer inifrån familjen.

\section{Inifråndiskursen}

\section{Underskott avmän}

I detta avsnitt kommer vi att belysa hur intervjupersonerna talar om familjen, eller föräldraparet i sig, på ett sätt som skapar bilden av en problematisk situation för barn med samkönade föräldrar. Lesbiska familjer, där två kvinnor fått barn inom sin relation, är i fokus i stor del av intervjumaterialet. I sättet att tala om den lesbiska familjen framhävs problem och svårigheter som knyts till könssammansättningen - två kvinnor - vilket bidrar till att den lesbiska familjen konstrueras som annorlunda, „den andra». Jämförelsen utgår ifrån den heterosexuella familjen, en manlig och en kvinnlig förälder med gemensamt barn, som norm. Den diskurs som vi benämner inifråndiskursen omfattar i sin tur två skilda problematiseringar, nämligen överskott av kvinnor respektive underskott av män.

Gemensamt för samtliga intervjuade psykologer är att man knyter an till föreställningen att ett barn behöver en kvinna och en man som förebild eller identifikationsobjekt, en bild som med automatik skapar ett antagande om tillkortakommande hos andra föräldrakonstellationer. I vad mån detta kan kompenseras framställs på olika sätt, där några intervjupersoner uttrycker att förebilder är något som tillgodoses spontant eller okomplicerat, via släkt och omgivning, medan andra väljer en framställning som är av mer dramatisk karaktär, med uttryck som »risk» och »identitetsförvirring", ifråga om konsekvenser för barnen. Genomgående skapas dessa framställningar med hjälp av en terminologi som anknyter till utvecklingspsykologisk teoribildning, med mer eller mindre tydlig förankring i psykodynamiskt tänkande. Här talas om ett behov hos barnen att identifiera sig med någon av föräldrarnas motsatta kön, ett behov som är grundläggande för dess psykologiska utveckling. I excerptet nedan talar intervjupersonen om förebilder som finns i »omgivningen". Utvecklingspsykologin är framlyft i excerptet genom intervjupersonens användande av begrepp som "identifikationsobjekt" och "anknytningen".

\section{Excerpt 4}

...finns det stabila förebilder, så att säga, $i$ omgivningen på olika sätt så kan man då hitta identi.. så kallade identifikationsobjekt ( $\mathrm{mm})$. Och utveckla den här anknytningen så att det inte blir någon total förvirring, identitets.. om man nu fär kalla det så, identitetsförvirring $i$ utvecklingen (ja, just det). IP 8

I intervjumaterialet finns en stor variation 
i hur barns behov av olikkönade förebilder eller identifikationsobjekt framförs. Vissa av intervjupersonerna knyter starkt an till en jämställdhetsdiskurs och framställer i huvudsak kvinnor och män som lika, medan andra istället framställer kvinnor och män som essentiellt olika där en specifikt kvinnlig funktion är att vårda de minsta barnen. Nedan illustreras avsaknaden av en man i lesbiska familjer och familjer med en ensamstående kvinnlig förälder.

\section{Excerpt 5}

...det finns bara kvinnor ( $\mathrm{mm}$ ) i hel.. kryllar av dem överallt.. så kan det ju bli problem för små pojkar att tänka sig det här att man inte fär leka med krigsleksaker eller att man fär liksom inte finns förståelse. Så de.. det är mer det här. men det måste.. de.. det kanske inte behöver hämma totalt.. men jag tror att pojkar leker annorlunda generellt än vad flickor gör ( $\mathrm{mm})$, men det gäller ju att föräldrar vill sina barns bästa ( $\mathrm{mm})$, någonstans $(\mathrm{mm})$, och försöker kanske hitta andra förebilder eller skapa relationer eller hur man nu kan lösa det, [...] om man tänker så här, för vissa sammanhang så finns det någon slags så här att man jourhavande kompis, då skulle man kunna tänka sig några [skratt] där det fanns liksom i lesbiska.. för lesbiska kvinnor man kunde höra av sig till.. det finns liksom män som man kan få kontakt med som kan vara kompispappa eller vad man ska nu kunna kalla det för. IP 5

I excerptet utpekas en brist på män genom uttrycket att "det finns bara kvinnor", vilket dramatiseras av intervjupersonen som att det »kryllar av dem överallt».
Uttrycket skapar en bild av kvinnliga föräldrar där vars och ens individuella egenskaper och karaktärer underordnas den kvinnliga identiteten, det som "kryllar" är inte särskilt viktigt var och en för sig. Den visar på en föreställning om essentiellt olika kön, liksom beskrivningen av att kvinnliga föräldrar skulle sakna "förståelse" för en pojkes "önskan" att leka med krigsleksaker. I denna framställning produceras föreställningar om kvinnligt och manligt föräldraskap som essentiella funktioner sett i relation till barn. Intervjupersonen använder sedan en retoriskt stark diskurs om föräldrar som "vill sina barns bästa", som ett sätt att framhäva uppgiften som två kvinnliga föräldrar skulle ha att »hitta andra förebilder«. I skämtsam ton framställs idén om en "kompispappa« att höra av sig till, som därmed $i$ konsekvens med antagandet om ett underskott på män skulle komplettera det lesbiska föräldraparet.

\section{Överskott avkvinnor}

I utredningen om assisterad befruktning, Ds 2004:19, ställs en fråga av praktisk natur: hur kan kvinnorna i ett lesbiskt par juridiskt benämnas på ett likvärdigt sätt utan att sammanblandas i de fall lagtexten specifikt hänvisar till den ena? I Psykologförbundets remissvar, liksom i intervjumaterialet, besvaras dock frågeställningen på ett sätt som innebär att möjligheten att barnet har två mödrar i psykologisk mening framstår som en omöjlighet. Genom att tala om personer av samma kön som "likadana", skapas föreställningen om att fler än en vuxen av varje kön skapar ett överskott. Det 
är en argumentation som i sin tur underbyggs av ett sätt att också värdera de båda kvinnornas roller i familjen, där biologiska band definieras på ett sätt som blir avgörande för vem av dem som utgör överskottet. Den kvinna i ett lesbiskt par som föder ett barn framställs i intervjumaterialet genomgående och på ett självklart sätt som "mor" eller "mamma" till barnet. Moderskap definieras därmed som i första hand en fråga om biologiska band. Den kvinna som inte fött barnet tillskrivs däremot ingen självklar funktion eller relation till barnet, utan får en position som ger upphov till diskussion och förhandling. Någon intervjuperson framställer båda kvinnorna som självklara mammor; betydligt vanligare är dock i intervjumaterialet att benämnande av den kvinna som inte fött barnet som "mor» avfärdas genom uttryck som att "det blir lite starkt att säga det«. Nedan ges ordet "mor» en tydlig definition.

\section{Excerpt 6}

Alltså, man kan ju inte kalla henne mor, för hon är ju inte mor. En mor är ju någon som har fött ett barn, eller tagit på sig att gå in i rollen för den som har fött ett barn. Och precis som vi pratade om barns behov, barn har ju behov utav att ha en mor $(\mathrm{mm})$. Sedan så finns det ju andra signifikanta vuxna naturligtvis, som är viktiga ( $\mathrm{mm}$ ), men de har ju alltid specifika benämningar (mm). Alltså, det är ju ett grundskott mot språket, så att säga ( $\mathrm{mm})$, att hävda att det skulle finnas.. nu finns det plötsligt två mödrar. IP 3

Här skapas en bild där den kvinna i ett lesbiskt par som inte fött barnet omöjligt kan uppfattas som mor. "En mor är ju någon som har fött ett barn, eller tagit på sig att gå in i rollen för den som har fött ett barn. " Definitionen tillåter biologiskt moderskap, liksom alternativet, moderskap genom adoption. Genom uttrycket "gå in i rollen för « markeras dock dels att det rör sig om ett andra alternativ, dels att det bara finns utrymme för en mor. För att möjliggöra ett psykosocialt moderskap, krävs enligt resonemanget att den biologiska modern är frånvarande. Moderskapet konstrueras här som en på förhand bestämd och färdig plats i familjen, som omöjliggör att barnet kan "mammas» av flera kvinnor samtidigt. Genom talet om moderskap och dess tydliga betydelsemässiga koppling till biologiska band framträder en moderskapsdiskurs. Den kvinna vars band till barnet inte är biologiska (men väl psykosociala och juridiska) exkluderas från möjligheten att tillskrivas moderskap. Detta påminner om den form av diskursiv diskriminering som Boréus benämner som just exkludering ur diskursen (Boréus 2006). Hon syftar då på tystnad eller osynliggörande av en viss grupp och deras röster inom diskursen. Här kan vi istället se hur den kvinna som inte fött barnet uttryckligen exkluderas från möjligheten att omfattas av moderskap och identifieras som mor.

I intervjumaterialet finns dock andra sätt att tala om henne, flera intervjupersoner vidrör möjligheten att fylla en vakant fadersroll i familjen. Dessa försök avslutas dock med kommentarer som att "det blir ju väldigt konstigt «. Samtidigt som den kvinna som inte fött barnet exkluderas från såväl moders- som fadersrollen skapas dock i flera intervjuer ett diskursivt utrymme för 
hennes föräldraskap, genom uttryck som att här "skapas ett annat föräldraskap". Kvinnan får då en roll till sitt barn utan att hon definieras som mamma eller pappa. Begreppet "förälder" rymmer på detta sätt möjligheter för nya roller och familjeformer, medan "mamma" och "pappa" terminologiskt framstår som låsta i en heterosexuell norm, eller förbehållna en biologisk förälder i en samkönad relation.

Den diskurs vi benämnt inifråndiskursen omfattar en problematisering av den lesbiska föräldrafamiljen. Samtidigt kan man dock konstatera att Psykologförbundet, liksom flertalet intervjupersoner, är positiva till möjligheten att utvidga lagstiftningen kring assisterad befruktning till att även omfatta lesbiska par. Vi ser här den form av diskursiv diskriminering Boréus benämner nedvärdering, i form av en stark problematisering av föräldraparets könssammansättning. Den diskriminerande strategin att presentera förslag som pekar på icke-språklig särbehandling används dock inte, till skillnad från när adoptionsfrågan var i fokus. Diskurserna utifrån och inifrån problematiserar båda regnbågsfamiljen, trots detta är det bara utifråndiskursen som resulterar i en negativ inställning till lagändring i riktning mot lika villkor. I slutdiskussionen kommer vi att resonera kring denna skillnad i fråga om inställning till kraven på likabehandling för homo- och heterosexuella par.

\section{Slutdiskussion}

Diskursanalysens stora poäng är att synliggöra hur en till synes logisk och begriplig uppfattning i själva verket bygger på specifika ställningstaganden och retoriska strategier som skapar bilden av en självklar och naturlig inställning. I de intervjuer vi analyserat konstrueras och rekonstrueras aspekter som biologi, psykologi, kön och sexualitet på ett sätt som skapar en normativ hierarki med avseende på familj, föräldraskap och barns utveckling. I intervjuerna konstrueras det samkönade föräldraskapet som "det andra». Detta "andra föräldraskap" kan beskrivas som skilt från det heterosexuella, olikt i den mening att könssammansättningen i föräldrakonstellationen skiljer sig åt. Vad som sker i intervjuerna är dock att denna olikhet också tillskrivs problem, eller nedvärderas, på ett sätt som synliggör att det heterosexuella föräldraskapet utgör den norm mot vilket allt annat jämförs - en heteronormativitet som skapar skillnader på den samkönade relationens bekostnad. ${ }^{6}$ Vi kan genomgående se hur problematiseringen av regnbågsfamiljer sker genom fokus endera på omgivningen eller på föräldraparets könssammansättning. Däremot nedvärderas eller kränks inte individens föräldraförmåga. Fokus på könssammansättning bildar här ett diskursivt mönster (Boréus 2006).

Det är ett diskursivt mönster i vilket den biologiska modern tillskrivs en unik position, vilket framgår då vi betraktar

6 Heteronormativitet syftar på ett föreskrivande normsystem i vilket heterosexualitet framställs som "naturligt» liksom det heterosexuella paret som en "självklar och riktig" utgångspunkt för familjebildning, vilket medför att icke-heterosexuella intima relationer och familjebildningar definieras som "annorlunda", "oriktiga» (Dahl 2005). 
utifrån- och inifråndiskursen samtidigt. I utifråndiskursen kan vi se hur det dubbla annorlundaskapet framställs som avgörande motiv till att upprätthålla skilda villkor för homosexuella par vid adoption. Det homosexuella föräldraskapet nedvärderas genom retoriska hänvisningar till negativa samhällsattityder till homosexualitet. Däremot problematiseras inte detta i frågan om assisterad befruktning för lesbiska par. Istället flyttas fokus till det lesbiska parets könssammansättning som, då det jämförs med en heterosexuell norm, ser ut att bestå av ett underskott av män och ett överskott av kvinnor. Vi ser hur den biologiska moderns närvaro tillskrivs en betydelse som hindrar problematisering, i dubbel bemärkelse. Dels säger man "ja» till assisterad befruktning, den fråga då barnet får en relation till sin biologiska mor. Dels framstår den biologiska moderns roll i familjen som självklar, medan hennes partner hamnar i fokus. Denna kvinnas roll blir istället föremål för en förhandling rörande betydelser och innebörder. Sammantaget växer en bild fram där moderskap på biologisk grund tillskrivs en självklarhet, som gör det omöjligt att ifrågasätta. Den diskursiva kopplingen mellan att ha biologiskt band till barnet, med dess sociala och kulturella betydelse, och att definieras som "mamma" och "mor" överbryggar de problem som homosexualiteten $i$ andra sammanhang tillskrivs.

Detta kan kanske förklara hur de homosexuella männen i stort sätt aldrig explicit omnämns, i vare sig remissvar eller intervjuer. För det första har assisterad befruktning hittills varit en fråga för heterosexuella och lesbiska par. Det innebär, för det andra, att manliga föräldrapar endast blir aktuella i adoptionsfrågan, det vill säga, den fråga där Psykologförbundet tydligt säger "nej». Förbundet avvisar därmed det lagförslag där "risken" finns att barnet växer upp utan en kvinnlig förälder, något som passar föreställningen om omvårdnad om små barn som en kvinnlig funktion väl. Samtidigt aktualiseras aldrig detta eftersom fokus i adoptionsargumentationen ligger utanför familjen, vilket bidrar till att frågan om det könade föräldraskapet blir dold. Frågan om två män som föräldrar behöver därmed inte uttalas eller omnämnas, utan förpassas till en tystnad. Här kan vi se den form av diskursiv diskriminering Boréus (2006) benämner exkludering ur diskursen, de homosexuella männen exkluderas från talet om föräldraskap överhuvudtaget.

Syftet med denna artikel har varit att analysera Psykologförbundets argumentation i frågan om lika villkor för homo- respektive heterosexuella par vid adoption respektive assisterad befruktning. Genom att fokusera den diskursiva diskrimineringens uttryck och specifika kännetecken har de retoriska elementen blivit tydligare, och den version av homosexuellas föräldraskap som skapas i argumentationen kan diskuteras just som det - en version som kan utmanas och som det finns alternativ till.

För att inte lämna läsaren med den problematiserande bild av homosexuellas föräldraskap som Psykologförbundets argumentation ger uttryck för, vill vi helt kort avsluta med att knyta an till det forskningsfält som vuxit fram de senaste åren, där regnbågsfamiljer som kategori inte problematiseras, utan där fokus istället ligger på variation och komplexitet inom katego- 
rin (för översikter se Anderssen et al.2002, Bigner 2006, Patterson 2006, Tasker \& Patterson 2007, Zetterqvist Nelson 2007). Det är forskning som frammanar grunderna för en alternativ diskurs om föräldraskap som lyfter fram relationens kvalitet som avgörande för att ge barn en god grund för utveckling, liksom stabila anknytningspersoner att växa upp med, alldeles oavsett dessas könssammansättning, antal eller biologiska/genetiska band till barnen.

I denna artikel fokuseras i huvudsak en lesbisk familj, två kvinnliga föräldrar till ett barn. Genom att framställa den kvinna som fött barnet som "mor» och tillskriva den kvinna som inte fött barnet en wannan föräldraroll« uppstår en rollfördelning i familjen. I praktiken är det dock inte ovanligt att lesbiska par skaffar flera barn, där kvinnorna delar på graviditeterna (Gartrell et al. 2006). I en familj där båda kvinnorna är biologisk mor blir det svårt att behålla föreställningen om en specifik rollfördelning när familjen ses som en dynamisk helhet. Vi menar att moderskap kan betraktas som en föränderlig, snarare än statisk, företeelse och att även biologi och genetik hanteras diskursivt och tillskrivs betydelser som är förhandlingsbara och föränderliga, där intervjupersonernas argumentation är en av flera tänkbara. Detta blir tydligt i en studie av Jones (2005) där brittiska lesbiska pars val av spermadonator synliggör skillnader mellan faktiska och föreställda genetiska band. Möjligheten för paret att, med hjälp av en donator med samma etniska bakgrund som den kvinna som inte föder barnet, skapa ett barn som utseendemässigt liknar båda, framställs som viktig, medan omöjligheten att skapa en faktisk gemensam genetisk avkomma framställs som betydelselös. Här blir det tydligt hur genetik och biologi medför faktiska möjligheter och begräsningar, vilket gör kvinnor och män, samoch olikkönade par, olika, samtidigt som vi kan välja hur vi diskursivt hanterar detta.

När en familjeform jämförs med en norm blir det, som vi visat, möjligt att framställa brister i den nya familjen. Därutöver förhindrar jämförandet också, som i det aktuella fallet, att regnbågsfamiljer gestaltas utifrån sina egna förutsättningar. De samkönade parens möjligheter att utmana eller omkonstruera genus, genom det manliga parets sätt att förändra tanken om primärt föräldraskap som en kvinnoangelägenhet (Zetterqvist Nelson 2006, 2007), eller det kvinnliga parets möjlighet att dela graviditeter mellan sig, ger upphov till nya modereller faderskap som är väl värda att belysas i sig själva. 


\section{Referenser}

Ahlin, Lars \& Hjelm, Åke (2004) "Yttrande över departementspromemorian Föräldraskap vid assisterad befruktning för homosexuella (Ds 2004:19)«. Hämtad 31 maj 2007 från http:// www.psykologforbundet.se.

Anderssen, Norman (2002) "Does contact with lesbians and gays lead to friendlier attitudes? A two year longitudinal study". Journal of Community \& Applied Social Psychology vol. 12 nr 2, s. 124-136.

Anderssen Norman, Amlie Christine \& Ytterøy Erling André (2002) "Outcomes for children with lesbian or gay parents. A review from studies 1978-2000«. Scandinavian Journal of Psychology vol. $43 \mathrm{nr}$ 4, s. 335-351.

Bigner, Jerry (2006) An introduction to LGBT family studies. New York: The Haworth Press Inc.

Billig, Michael (1991) Ideology and opinions: studies in rhetorical psychology. London: Sage.

Boréus, Kristina (2005) „Diskursiv diskriminering. En typologi«. Statsvetenskaplig tidskrift vol. 107 nr 2, s. 119-139.

Boréus, Kristina (2006) "Discursive Discrimination. A Typology". European Journal of Social Theoryvol. $9 \mathrm{nr}$ 3, s. 405-434.

Clarke, Victoria (2000) "Stereotype, attack and stigmatize those who disagree': employing scientific rhetoric in debates about lesbian and gay parentingu. Feminism \& Psychology vol. $10 \mathrm{nr}$ 1, s. 152-159.

Clarke, Victoria (2001) "What about the children? Arguments against lesbian and gay parenting". Women Studies International Forum vol. 24 nr 5, s. 555-570.

Dahl, Ulrika (2005) "Scener ur ett äktenskap». I Don Kulick (red.) Queersverige. Stockholm: Natur och Kultur.

Danielsson, Torgny \& Graff-Cederström, Karin (2001) "Barn i homosexuella familjer (SOU 2001:10)«. Hämtad 31 maj 2007 från http:// www.psykologforbundet.se

Ds 2004:19 Föräldraskap vid assisterad befruktning för homosexuella. Stockholm: Fritzes offentliga publikationer.

Edwards, Derek \& Potter, Jonathan (1992) Discur- sive psychology. London: Sage.

Essed, Philomena (1991) Understanding everyday racism: an interdisciplinary theory. London: Sage.

Gartrell Nanette, Rodas Carla, Deck Amalia, Peyser Heidi \& Banks Amy (2006) »The USA national lesbian family study: interviews with mothers of 10-year-olds". Feminism \& Psychologyvol. $16 \mathrm{nr} 2$, s. 175-192.

Herek, Gregory M. (2002) „Sexual prejudice and gender: do heterosexuals' attitudes toward lesbians and gay men differ?" Journal of Social Issues vol. $56 \mathrm{nr} 2$, s. 251-266.

Jones, Caroline (2005) „Looking like a family: negotiating bio-genetic continuity in British lesbian families using licensed donor insemination". Sexualities vol. $8 \mathrm{nr} 2$, s. 221-237.

Ju 03.03 Partnerskap och adoption m.m.

Magnusson, Eva (2006) Hon, han och hemmet: genuspsykologiskaperspektivpå vardagslivet i nordiska barnfamiljer. Stockholm: Natur och Kultur.

Malmquist, Anna (2007) Psykologförbundet och regnbaigsfamiljerna. En diskursanalytisk studie av konfliktpunkter mellan Sveriges Psykologförbund och homosexuellas familjebildningar. Psykologexamensuppsats. Linköping: Linköpings universitet.

Patterson, Charlotte (2006) "Children of lesbian and gay parents". Current Directions in Psychological Science vol. $15 \mathrm{nr}$ 5, s. 241-244.

Potter, Jonathan \& Wetherell, Margaret (1987) Discourse and social psychology. London: Sage.

Proposition 2001/02:123 Partnerskap och adoption.

Proposition 2004/05:137 Assisterad befruktning och föräldraskap.

Ratcliff Jennifer, Lassiter Daniel, Markman Keith \& Snyder Celeste (2006) "Gender differences in attitudes toward gay men and lesbians". Personality and Social Psychology Bulletin vol. 32 nr 10, s. 1325-1338.

Riksdagens snabbprotokoll 2001/02:120 Onsdagen den 5 juni (2002, 5 juni) Hämtad 19 augusti 2008 från http://www.riksdagen.se

SFS 1994:1117 Lag om registrerat partnerskap.

SFS 2006:351 Lag om genetisk integritet m.m.

SOU 1983:42 Barn genom insemination. Stockholm: Allmänna förlaget. 
SOU 1984:63 Homosexuella och samhället. Stockholm: Liber.

SOU 1993: 98 Partnerskap. Stockholm: Allmänna förlaget.

SOU 2001:10 Barn i homosexuella familjer. Stockholm: Fritzes offentliga publikationer.

SOU 2007:3 Föräldraskap vid assisterad befruktning. Stockholm: Fritze.

Speer, Susan A. \& Potter, Jonathan (2000) »The management of heterosexist talk: conversational resources and prejudiced claims". Discourse \& Societyvol. $11 \mathrm{nr} 4$, s. 543-572.
Tasker, Fiona \& Patterson, Charlotte (2007) "Research on gay and lesbian parenting: retrospect and prospectu. Journal of GLBT Family Studies vol. $3 \mathrm{nr}$ 2-3, s. 9-34.

Zetterqvist Nelson, Karin (2006) "Att vara pappa i homofamiljer - berättelser om barn, mammor och familjeliv». Socialvetenskaplig Tidskrift vol. $13 \mathrm{nr} \mathrm{1,} \mathrm{s.} \mathrm{66-86.}$

Zetterqvist Nelson, Karin (2007) Mot alla odds. Regnbågsföräldrars berättelser om att bilda familj och fåbarn. Malmö: Liber.

\section{Summary}

\section{Discursive discrimination of lesbigayfamilies An analysis of argumentation considering Swedish legislative changes of lesbian and gay parenthood}

Since the beginning of the twenty-first century two legislative changes have increased rights and possibilities for Swedish lesbian and gay parents. Same-sex couples today benefit from the same judicial status as heterosexual couples concerning adoption and assisted reproduction. Even though changes have been accomplished, this is an outcome of a debate.

The Swedish Psychological Association (SPA) was one among a number of bodies to which the proposed legislative measure was referred for consideration. SPA disapproved of the proposal for equal rights for adoption, and the aim of this article is to analyse the rhetorical argumentation that grounded their statement.

Our analysis in this article is based on Kristina Boréus's typology of discursive discrimination, as well as the discursive psychology of Eva Magnusson. In nine semi-structured qualitative interviews the management of SPA reflects on lesbigay families and the statements of the Association.

Two major discourses which form the discursive discrimination were found as an outcome of the study. In the first discourse children in lesbigay families are said to be exposed to social stressors within a homophobic society. Such rhetorical arguments are frequently formulated when the interviewees discuss adoption, which supports the disapproval of the same-rights proposal. The second identified discourse concerns assisted reproduction for lesbian couples. Here, the possibility of two mothers to a child is questioned and the non-birth-giving woman is included in parenthood, but excluded from motherhood. Role models of both sexes are also stressed as important to the child, which makes two women look like a mismatched couple in parenthood. By making heteronormativity visible in analysis of the discourses one gets the opportunity to understand lesbigay families differently. 